\title{
TESTICULAR DEVELOPMENT IN RATS TREATED WITH SEVERAL STEROIDS SHORTLY AFTER BIRTH
}

\author{
W. LADOSKY AND W. M. KESIKOWSKI* \\ Department of Physiology, Fac. Ciências Médicas, Univ. Católica do Paraná, \\ Curitiba Paraná, Brazil
}

(Received 30th May 1968, revised 1st October 1968)

\begin{abstract}
Summary. One-day-old male rats received a single injection of oestradiol benzoate, testosterone propionate or one of three testosterone derivatives in order to study their action on testicular development, particularly spermatogenesis. All substances caused a delay of spermatogenesis, observed when rats were killed at 35 or 60 days of age. These effects were reversible and testis histology as well as fertility were restored by the time the animals were 90 days old. Seminal vesicles at 90 days were under-developed in all but oestrogen-treated rats which may indicate impairment of ICSH liberation.

Testicular growth is more powerfully inhibited by drugs bearing hydroxylated instead of oxygenated $\mathrm{C}_{3}$. The combinations of $\mathrm{C}_{3}-\mathrm{OH}$ and $\mathrm{C}_{17}=0$ give stronger inhibition than any other.
\end{abstract}

\section{INTRODUCTION}

Previous investigations have demonstrated that female rats receiving a single dose of testosterone propionate (TP) shortly after birth develop permanent sterility; follicles fail to ovulate and corpora lutea do not develop (Bradbury, 1941 ; Segal \& Johnson, 1959; Barraclough, 1961 ; Martins, Ladosky \& Velloso, 1961). Permanent sterility was also observed in rats injected with oestradiol benzoate (OB) (Gorski, 1963); 19-nortestosterone (Jacobsohn, 1964) and progesterone (Hale, 1944; Takasugi, 1954).

In male rats, however, evidence of irreversible sterility is not so clear-cut. Swanson \& van der Werff ten Bosch (1964) observed that a single dose of TP $(0.5 \mathrm{mg})$ injected on the 5 th day after birth inhibited body growth and testicular development but not spermatogenesis in rats at 120 days of age. Johnson \& Witschi (1963) confirmed these results in animals at the 60th day. Maqueo \& Kincl (1964) observed normal testicular maturation at Days 44 to 55 in rats also treated with TP on the 5th day after birth. A dose-response relationship was also observed for inhibition of testicular development, but not for impairment of spermatogenesis (Kincl, Folch Pi, Maqueo, Lasso, Oriol \& Dorfman, 1965). On the other hand, Mayer \& Thevenot-Duluc (1962) reported inhibition of spermatogenesis on Day 90 in rats androgenized on the 5th day of life.

* Fellow from the Conselho Nacional de Pesquisas. 
Results with OB are more consistent; a single dose on the 5th day after birth caused inhibition of testicular development, impaired spermatogenesis and atrophy of the accessory genitalia in 60-day-old rats (Harris \& Levine, 1962; Kincl, Folch Pi \& Lasso, 1963; Maqueo \& Kincl, 1964). Since these data are in conflict with the reports of recovery of spermatogenesis after TP injection, the present work was undertaken to study the possibility of testicular recovery after OB treatment in rats killed at a later stage than 60 days after birth. The effect of injections of oestrogen was compared with that of testosterone and certain testosterone derivatives.

Preliminary data were reported at the meeting of the Brazilian Association for the Advancement of Science (Ladosky \& Kesikowski, 1965).

\section{MATERIAL AND METHODS}

Ninety male Wistar rats, bred in the authors' colony, were injected with 100 $\mu \mathrm{g}$ of one of the following substances within the first $24 \mathrm{hr}$ after birth: (1) oestradiol benzoate (OB); (2) testosterone propionate (TP); (3) methyl hydroxyandrostenedione (MHA); (4) methylandrostenolone (MA); (5) chlorotestosterone acetate (CTA). Eighteen rats were kept as untreated controls.

The dosage of testosterone derivatives used had been previously tested in adult, castrated, male rats and proved ineffective in maintaining seminal vesicle weight. A soybean suspension of the test-substance was injected subcutaneously in a total volume of $0.2 \mathrm{ml}$.

To avoid body weight differences due to feeding competition, each mother nursed six young, all of which were weaned at Day 30 . Gonadal differences due to seasonal variation were avoided by performing all the experiments on rats born between 18th May and 20th July.

At 35, 60 and 90 days after birth, six animals that were not litter mates were taken from each treatment group, and caged with proven fertile females to test fertility. After 3 days, they were killed with ether. At autopsy, the right testis, right epididymis, both seminal vesicles with the prostate, the right adrenal and the hypophysis were removed and weighed. Soon after removal, the left epididymis was minced with fine scissors, suspended in warm saline and the suspension was examined by dark-ground microscopy for spermatozoa. For histological examination, tissues were fixed in Bouin's fluid and stained with iron haematoxylin and eosin. Spermatogenesis was rated according to the classification of Heller \& Clermont (1964), and interstitial cell maturation according to that of Hooker (1944).

\section{RESULTS}

Influence of treatment on body and tissue weight

As seen in Table 1, no correlation could be found either at 35 or at 90 days of age between the growth-promoting action and the testicular inhibitory activity. At 35 days, only rats treated with MHA had body weights greater than those of the controls associated with a depression of testicular weight. TP- and 


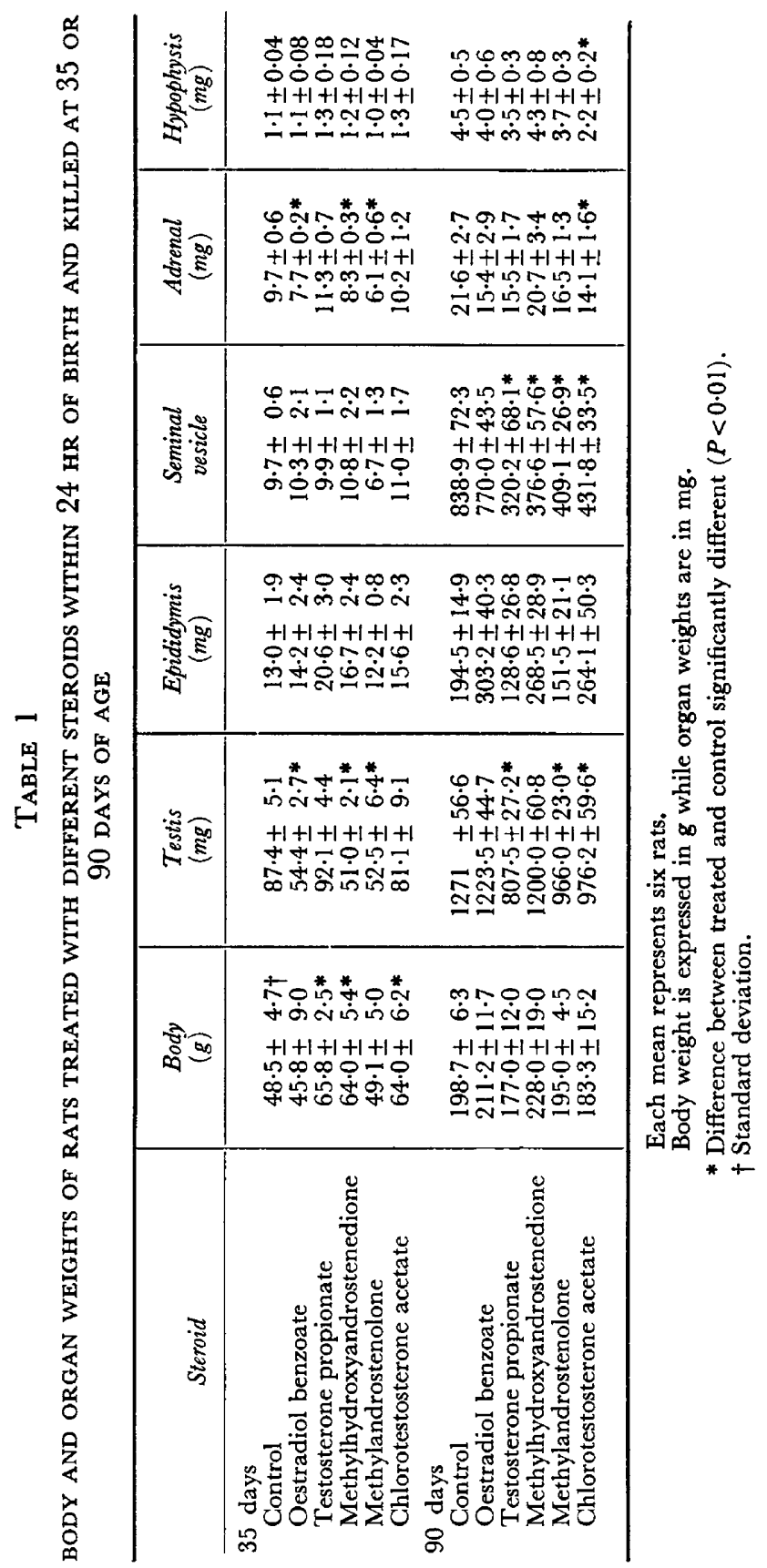


CTA-treatment caused anabolic activity without gonadal influence, while OB and MA significantly depressed testicular weight, but did not interfere with body growth. In 90-day-old rats, the dissociation between the anabolic and testicular effects of the test-substances was more clear-cut; although their body weight was comparable to that of the untreated controls, rats injected with TP, MA and CTA showed significant depression of testicular weight.

At 35 days, gonadal depression was accompanied by a reduced number of seminiferous tubules (Table 2), and was closely related to adrenal hypoplasia, possibly due to a general inhibition of the hypothalamic-hypophysial axis. The fact that the weights of the seminal vesicles were not significantly different from those of the controls might be explained either by the fact that the animals were still pre-puberal or because the IcsH-releasing mechanism was not really disturbed by the steroids injected at the day of birth. The first hypothesis seems the more likely, since the seminal vesicles of rats killed at 90 days after birth were severely depressed in all groups but the OB-injected group.

TABLE 2

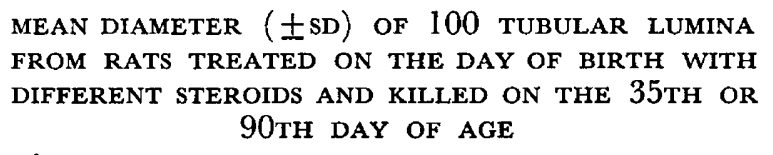

\begin{tabular}{l|c|c}
\hline \multirow{2}{*}{} & \multicolumn{2}{|c}{ Diameter of tubular lamina $(\mu)$} \\
\cline { 2 - 3 } & 35 th day & 90 th day \\
\hline Control & $3 \cdot 2 \pm 0 \cdot 08$ & $7 \cdot 4 \pm 0 \cdot 1$ \\
Oestradiol benzoate & $2 \cdot 4 \pm 0 \cdot 1^{*}$ & $7 \cdot 4 \pm 0 \cdot 09$ \\
Testosterone propionate & $3 \cdot 1 \pm 0 \cdot 09$ & $7 \cdot 2 \pm 0 \cdot 08$ \\
Methylhydroxyandrostenedione & $2 \cdot 6 \pm 0 \cdot 09^{*}$ & $7 \cdot 2 \pm 0 \cdot 1$ \\
Methylandrostenolone & $2 \cdot 2 \pm 0 \cdot 08^{*}$ & $7 \cdot 1 \pm 0 \cdot 11$ \\
Chlorotestosterone & $3 \cdot 3 \pm 0 \cdot 07$ & $7 \cdot 4 \pm 0 \cdot 08$ \\
& & \\
\hline
\end{tabular}

Each mean represents six rats.

* Significantly different from controls $(P<0 \cdot 01)$.

As the testicular impairment at 90 days was not accompanied by reduction in the size of tubular lumina (Table 2), retarded spermatogenesis (Plate 3) or adrenal hypoplasia (Table 1), but was followed by a significant reduction in the weight of the seminal vesicles, it is possible that there is some reduction in the secretion of ICSH by the pituitary gland.

\section{Steroid action on sperm maturation}

At 35 days, the seminiferous tubules of control rats (Pl. 1, Fig. A) were well organized and showed maturation to the primary spermatocyte stage in pachytene. The basement membrane was thick and the interstitial cells presented a small, central, round nucleus, and condensed cytoplasm containing a few vacuoles and inclusions. In the OB-treated group (Pl. 1, Fig. B), some tubules were distorted and a few germinal cells were in the leptotene phase of spermatocyte development, while the majority remained at the spermatogonial 
PIATTE

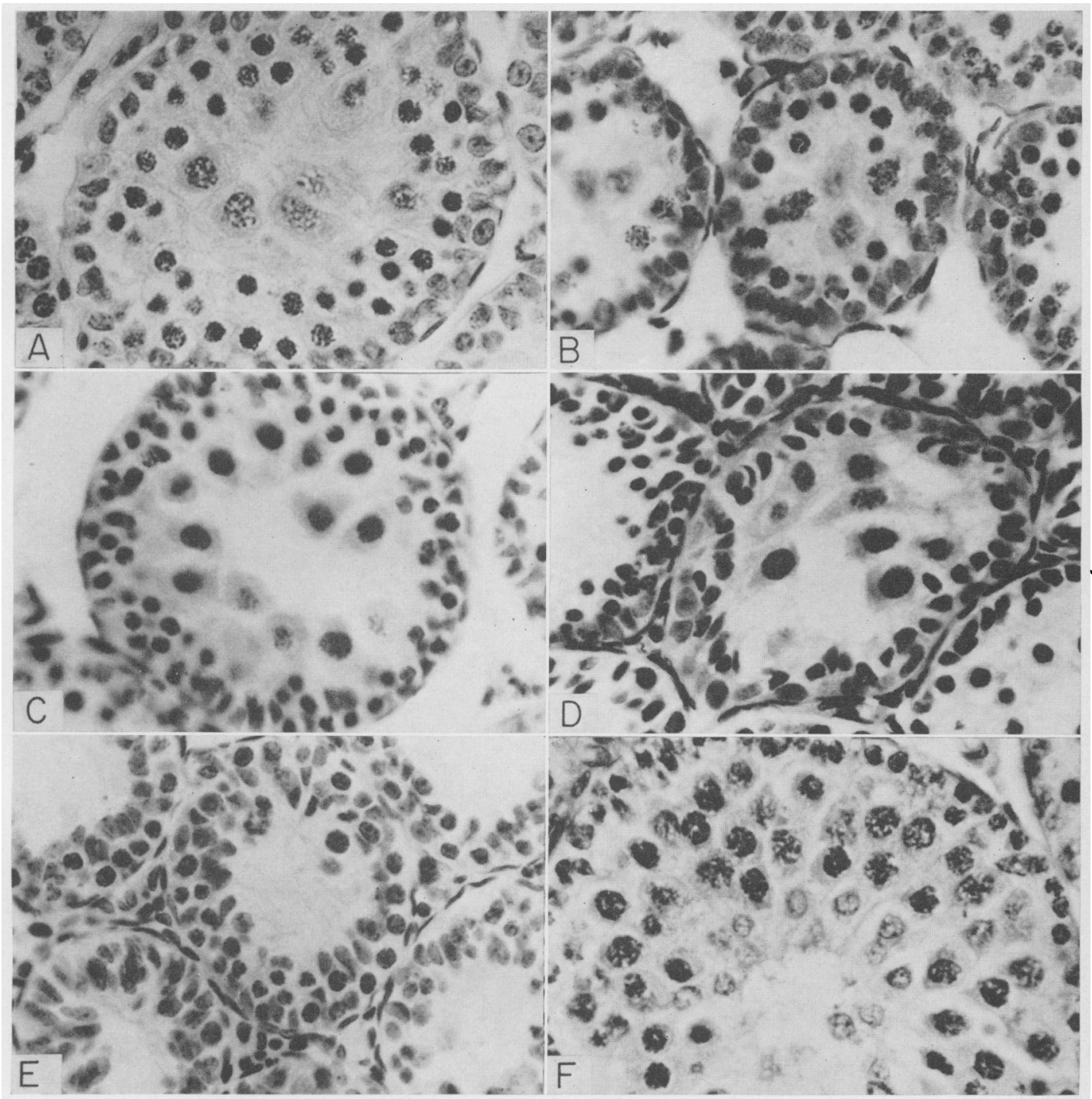

Testis from 35-day-old rats injected with different stcroids on the day of birth. Ironhaematoxylin and eosin, $\times 80$.

A. Control. Maturation to primary spermatocyte stage in the pachytene phase.

B. Oestrogen. Distorted tubules with spermatogonia and a few spermatocytes in the leptotene phase.

C. Testosterone. Maturation to primary spermatocyte stage only,

D. MHA. Strong inhibition of sperm maturation. Majority of spermatocytes seen in leptotene with $\mathrm{few}$ in the zygotene phase.

E. MA. Gcrm-cell maturation to primary spermatocyte stage in leptotene.

F. CTA. Spcrmatogenic maturation comparable to that of controls. Spermatocytes in a more advanced phase of pachytene than controls. 
PIA'TE '2

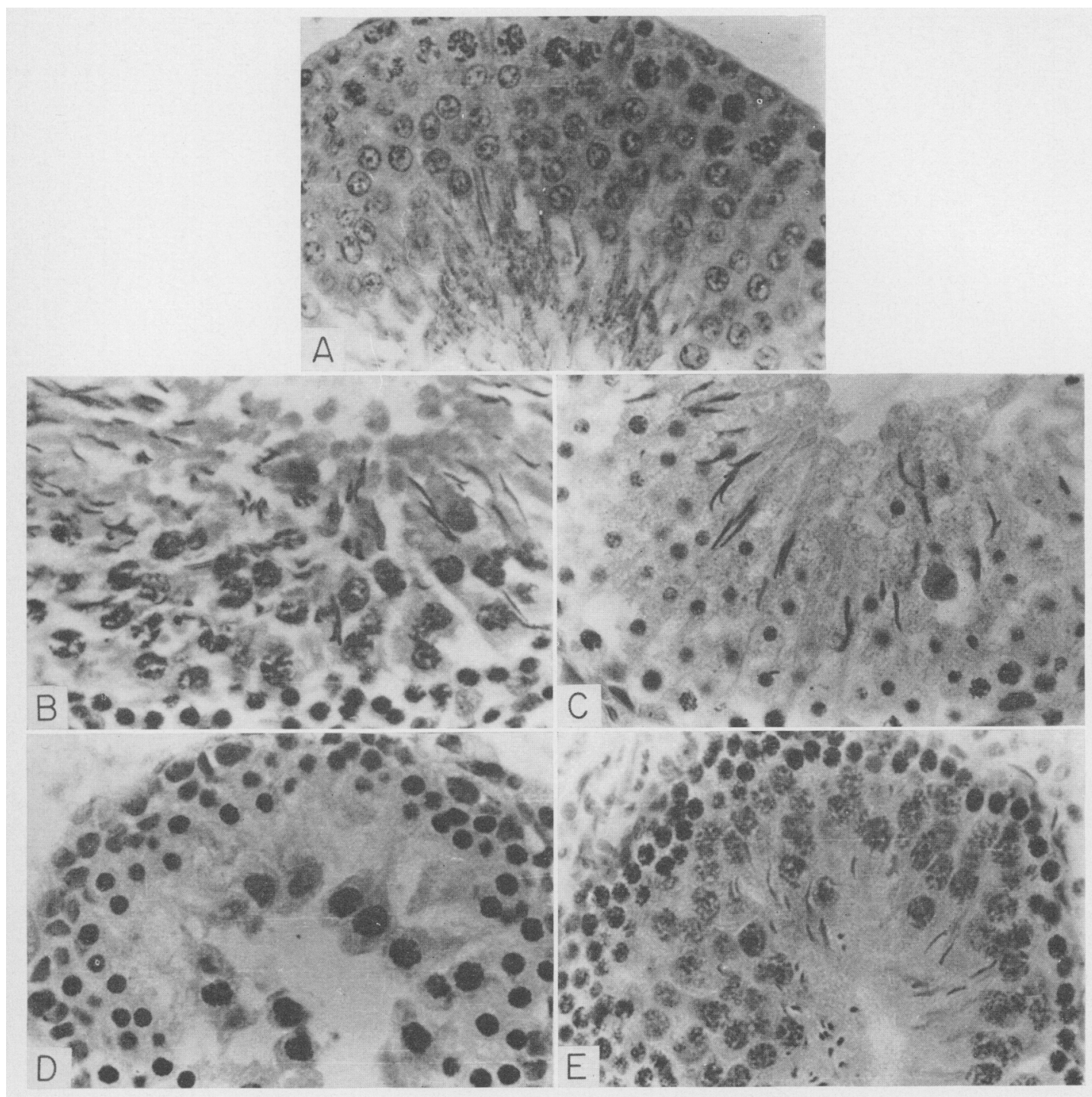

Testis from 60-day-old rats injected with different steroids on the day of birth. Ironhamatoxylin, $\times 350$.

A. Control. Complete maturation of germinal cells. Spermatozoa present in the lumen of seminal tubules.

B. Testosterone. Germ-cell maturation developed to spermatid stage and some spermatozoa also visible.

C. MHA. Tubule showing development to early maturation.

D. MA. Spermatocytes seen in pachytene phase.

E. Germ cell maturation restricted to spermatid stage. Rats were sterile. 


\section{PI.XIL: 3}

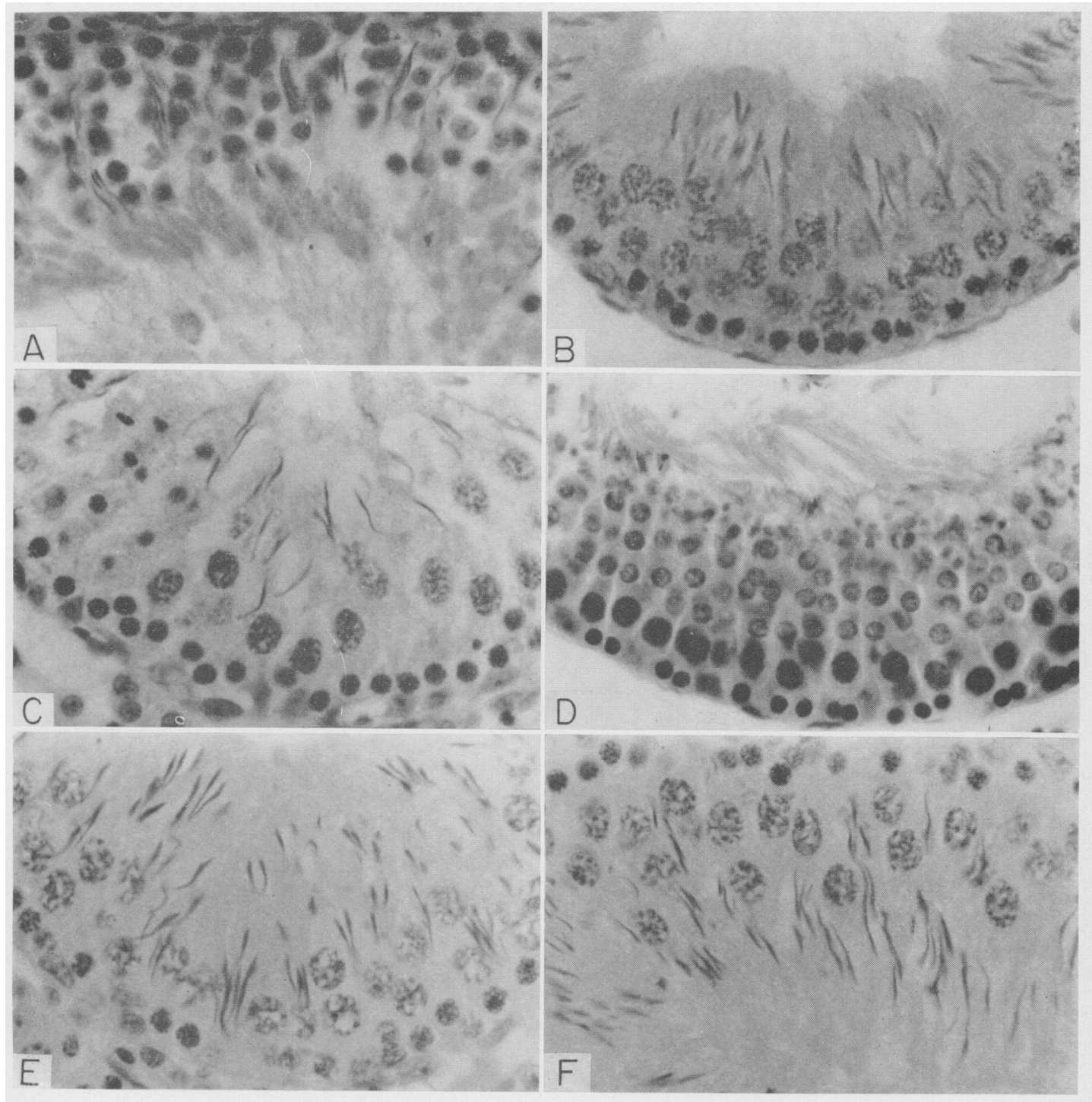

Testis from 90-day-old rats injected with different steroids on the day of birth. Ironhacmatoxylin and eosin. $\times 330$.

1. Control B. Oestrogen; C: Testosterone; D), MHA ; L. MA; F, CTA.

Irrespective of treatment, all sections show full germ-cell maturation to spermatozoa formation. 
stage. Leydig cells were in a metamorphic phase. In TP-treated rats (Pl. 1, Fig. G), tubules appeared to be well organized with a smooth basement membrane. Maturation of the germinal cells, however, only reached the primary spermatocyte stage. As in controls, Leydig cells were small and immature. MHA (Pl. 1, Fig. D) inhibited germ-cell maturation so that the majority of spermatocytes were only seen in leptotene and very few could be observed in zygotene. Interstitial cells again showed small, round nuclei but the cytoplasm contained no vacuoles and was poorly-staining. In the MAtreated group (Pl. 1, Fig. E), germ-cell maturation was restricted to primary spermatocytes in interphase with a few spermatocytes in leptotene. The Leydig cells did not differ greatly from those of the controls. In CTA-treated rats (Pl. 1, Fig. F), neither the tubules nor the Leydig cells differed from those of the controls. Germinal cells were in the pachytene phase and a little more fully developed than those of controls.

At Day 60, the seminiferous tubules in the controls (P1. 2, Fig. A) were well organized. Spermatozoa were found within the lumen of the tubules as well as in the epididymis. When placed with females, these rats proved to be fertile. Leydig cells were mature with a round, excentric nucleus and vacuoles and inclusions in the cytoplasm. In TP-treated rats (Pl. 2, Fig. B), germ-cell maturation developed to the spermatid stage and a few spermatozoa were also found in the tubules as well as in the epididymis, but only three out of six rats were fertile. Leydig cells were mature. In the MHA-treated group (Pl. 2, Fig. G), a few tubules showed germ-cell development up to early maturation, but no spermatozoa were found in the tubules or epididymis and the rats were sterile. In the MA-treated group (Pl. 2, Fig. D), spermatocytes had only developed to pachytene and the animals were sterile. No spermatozoa were found in the epididymis. Leydig cells showed the final differentiation from the immature phase. In CTA-treated rats (Pl. 2, Fig. E), germ-cell maturation was restricted to the spermatid stage and no mature spermatozoa were found in the lumen of the tubules or in the epididymis and the rats were sterile. The Leydig cells of the treated rats were comparable to those of the controls.

At Day 90 (Plate 3), all rats, irrespective of treatment, presented a normal tubular epithelium with a germ-cell line fully developed to mature spermatozoa. All animals proved to be fertile. The Leydig cells did not differ from those of controls, and had undergone complete maturation.

\section{DISGUSSION}

Observations on male rats treated on the day of birth with different steroids revealed that TP and testosterone derivatives act on the hypothalamus of the newborn male rat, inhibiting pituitary activity. The gland partially recovers within 90 days, particularly with regard to the secretion of FSH and ACTH. Liberation of ICsH and secretion of testosterone, however, is impaired as shown by the hypoplasia of the seminal vesicles at 90 days. OB, on the contrary, exerts only a transient inhibitory effect on the hypothalamic-hypophysial axis without any permanent impairment of ICSH secretion. Disagreement with the results of Harris \& Levine (1962), Kincl et al. (1963), Johnson, Yasuda \& 
Sridharan (1964) and Maqueo \& Kincl (1964), who stated that OB as well as some testosterone derivatives could irreversibly inhibit spermatogenesis, is explained by the difference in age at which the animals were killed. At 60 days, i.e. the latest age in the studies cited above, germ-cell maturation is still retarded by the treatments and the animals are infertile. When more time is allowed for recovery and autopsy is delayed to 90 days of age, spermatozoa attain complete maturation and the animals become fertile. Our results are in good agreement with those of Swanson \& van der Werff ten Bosch (1964), Johnson \& Witschi (1963) and Kincl, Maqueo \& Dorfman (1965), who reported a transient inhibition of spermatogenesis after TP injection.

In contrast to results in females (Bradbury, 1941; Segal \& Johnson, 1959; Barraclough, 1961; Martins et al., 1961; Swanson \& van der Werff ten Bosch, 1964), neither TP nor OB, nor synthetic testosterone derivatives caused permanent sterility in males. It is probable, therefore, that they do not affect the organization of the nervous structures which control the male pattern of gonadotrophin secretion. Testicular inhibition observed at 35 days of age may be due to a changed balance of FSH and ICSH secretion due to disturbances in the neural control of the pituitary gland as already suggested for a similar situation in the female (Swanson \& van der Werff ten Bosch, 1964; Jacobsohn, 1964) in whom the impairment of ICSH is known to be more consistent and long-lasting than that of FSH. However, as ovulation is more dependent on LH liberation by the hypophysis than is spermatogenesis, the decreased liberation of this gonadotrophin is more dramatically observed in the former than in the latter sex.

The male neonatal hypothalamus may be less sensitive to testosterone than the female. If so, this may be due to the fact that the male hypothalamus is already differentiated at birth and refractory to steroids, or to the fact that steroids act like some endogenous substance as an organizer of sexual centres in the brain, thereby reinforcing masculine differentiation. Harris \& Levine (1962) suggested that the male hypothalamus is already organized at birth since they could not modify its pattern of gonadotrophin liberation with neonatal injections of testosterone or oestrogen; but, since castration of newborn males (Pfeiffer, 1936; Harris, 1964; Ladosky, 1964) prevents brain differentiation and induces a gonadal control comparable to that of females, it could be argued that the male hypothalamus is still undifferentiated at the moment of birth. TP and other steroids may act like endogenous testicular hormones in the organization of a male pattern of pituitary control by lowering the output of ICSH from the gland. On this view, male newborn rats are as sensitive to androgenic substances as female neonates in regard to differentiation of $\mathbf{L H} / \mathbf{I C S H}$ controlling mechanisms. By contrast, $\mathrm{OB}$ is active only in females (Hale, 1944; Takasugi, 1952; Ladosky, 1967).

Substances with hydroxylated $\mathrm{C}_{3}$ (MA and $\mathrm{OB}$ ) are more powerful than the oxygenated compounds in their action on the delay of testicular growth and maturation of spermatozoa (Table 2). Since MA, the most potent inhibiting drug used in this study, also has an oxygenated $\mathrm{C}_{17}$ unlike all the others, it seems likely that the combination $\mathrm{C}_{3}-\mathrm{OH}$ plus $\mathrm{C}_{17}=0$ gives the greatest activity. Double-bonding and its position in the A ring does not seem to interfere with testicular inhibition. MA and CTA, respectively the stronger and the 
weaker inhibitors, are both $\Delta 4$ steroids. MHA is as potent as CTA in spite of having two double bonds $(\Delta 1,4)$.

In females, the authors have observed a difference in anabolic and androgenic activity (Jacobsohn, 1964). CTA, in spite of having the same structure as TP with an extra chloride at $\mathrm{C}_{\mathbf{4}}$, has the same anabolic but a milder androgenic action. The imprinting action on the brain may, therefore, depend not on the molecule as a whole but on the radicals responsible for androgenic activity, allowing for the fact that the steroids used were in a dose range insufficient to produce androgenic activity.

\section{ACKNOWLEDGMENTS}

This study was supported by a grant from the Conselho Nacional de Pesquisas. We wish to thank Dr H. Swanson for her interest, helpful criticisms and suggestions as well as the revision of the manuscript.

\section{REFERENCES}

Barraclough, C. A. (1961) Production of anovulatory, sterile rats by single injection of testosterone propionate. Endocrinology, 68, 62.

Bradbury, J. T. (1941) Permanent effects following masculinization of the infantile female rat. Endocrinology, 28, 101 .

Gorsxi, R. A. (1963) Modification of ovulatory mechanism by post-natal administration of oestrogen to the rat. Am. F. Physiol. 205, 842.

HALE, H. B. (1944) Functional and morphological alterations of the reproductive system of the female rat following prepuberal treatment with estrogens. Endocrinology, 35, 499.

HARRIS, G. W. (1964) Sex hormones, brain development and brain function. Endocrinology, 75, 627.

Harris, G. W. \& Levine, S. (1962) Sexual differentiation of the brain and its experimental control. 7. Physiol., Lond. 163, 42P.

Heller, G. G. \& Glermont, Y. (1964) Kinetics of the germinal epithelium in man. Recent Prog. Horm. Res. 20, 545.

Hooker, C. W. (1944) The post-natal history and functions of the interstitial cells of the testis of the bull. Am. F. Anat. 74, 1 .

Jacobsohn, D. (1964) Development of female rats injected shortly after birth with testosterone or 'anabolic steroids'. Acta endocr., Copenh. 45, 402.

Johnson, D. C. \& Wirschr, E. (1963) Hypophyseal gonadotrophins following gonadectomy in male and female androgenized rats. Acta endocr., Copenh. 44, 119.

Johnson, D. C., Yasuda, M. \& SRidharan, B. N. (1964) Prepuberal development of the androgenized male rat. J. Endocr. 29, 95.

Kincl, F. A., Folch Pi, A. \& Lasso, L.H. (1963) Effect of oestradiol benzoate treatment in the newborn male rat. Endocrinology, 72, 966.

Kincl, F. A., Folch Pi, A., Maqueo, M., Lasso, L. H., Oriol, A. \& Dorfmann, R. I. (1965) Inhibition of sexual development in male and female rats treated with various steroids at the age of 5 days. Acta endocr., Copenh. 49, 193.

Kincl, F. A., Maqueo, M. \& Dorfman, R. I. (1965) Influence of various steroids on the testis and accessory sex organs in the rat. Acta endocr., Copenh. 49, 145.

Kincl, F. A., Maqueo, M. \& Folch Pi, A. (1964) Recovery of gonadal function in male rats treated neonatally with 17 oestradiol benzoate. Acta endocr., Copenh. 47, 200.

LAdosky, W. (1964) Sôbre a possibilidade de feminização do hipotálamo de macho. Anais Acad. bras. Ciênc. 36, 367R.

LADOSKy, W. (1967) Anovulatory sterility in rats neonatally injected with stilbestrol. Endokrinologie, $52,259$.

LADosky, W. \& Kesıkowski, W. M. (1965) Influência da injeção neonatal de esteróides no desenvolvimento testicular de ratos. Anais Acad. bras. Ciênc. 37, 577.

Maqueo, M. \& Kincl, F. A. (1964) Testicular histo-morphology of the young rats treated with estradiol 17 benzoate. Acta endocr., Copenh. 46, 25.

Martins, T., Ladosky, W. \& Velloso, L. F. (1961) Masculinização do tipo cronologico da atividade do ovario por efeito central da testosterona injetada em recem-nascidos. Anais Acad. bras. Ciênc. $34,43 R$. 
Mayer, G. \& Thevenot Duluc, A. J. (1962) Evolution des greffes intraspléniques d'ovaries chez la ratte en lactation. C.r. Séanc. Soc. Biol. 156, 76.

Pfeiffer, C. A. (1936) Sexual differences of the hypophysis and their determination by the gonads. Am. F. Anat. 58; 195.

Segal, S. J. \& Johnson, D. C. (1959) Inductive influence of steroid hormone on the neural system: ovulation controlling mechanism. Archs Anat. microsc. Morph. exp. 48, 261. (Suppl.).

Swanson, H. E. \& VAN DER WERFF TEN Bosch, J. J. (1964) The early androgen syndrome; differences in response to pre-natal and post-natal administration of various doses of testosterone propionate in female and male rats. Acta endocr., Copenh. 47, 37.

TAkasugi, N. (1952) Einflusse von Androgen und Estrogen auf die Ovarien der Meugeborenen und Reifen, Weiblichen Ratten. Annotnes. zool. jap. 25, 120.

Takasugr, N. (1954) Einflusse von Androgen und Progestogen auf die Ovarien der Ratten, denen sofort nach der Gebert Oestrogeninjektion durchgefuhrt wurde. 7. Fac. Sci., Tokyo, 7, 299. 